\title{
Pollution menacing Lake Victoria: Quantification of point sources around Jinja Town, Uganda
}

\author{
Hannington W Oguttu ${ }^{1}$, Fred WB Bugenyi ${ }^{2}$, Heinz Leuenberger ${ }^{3}$, Markus Wolf ${ }^{4}$ and Reinhard Bachofen ${ }^{5 *}$ \\ ${ }^{1}$ Fisheries Resources Research Institute, FIRRI, Jinja, PO Box 343, Jinja, Uganda \\ ${ }^{2}$ Makerere University, Department of Zoology, PO Box 7062, Kampala, Uganda \\ ${ }^{3}$ VNCPC, Institute of Environmental Science and Technology, Hanoi University of Technology, Hanoi, Vietnam \\ ${ }^{4}$ University of Applied Sciences Basel, Institute of Environmental Technology, St. Jakobsstr. 84, CH-4132 Muttenz, Switzerland \\ ${ }^{5}$ University of Zurich, Institute of Plant Biology, Zollikerstr. 107, CH-8008 Zürich, Switzerland
}

\begin{abstract}
Lake Victoria is Africa's largest tropical freshwater lake, important as a source of drinking water and as a source of food for the population in the surrounding region. Due to increased human activities in agriculture and industry during the past decades a continuously increasing inflow of agricultural runoff has been observed, and lately there have also been increased discharges of municipal effluents and industrial wastewater into Lake Victoria. This paper summarises the results of a oneyear (1997 to 1998) environmental and ecological study of industrial wastewater point sources in the Jinja (Uganda) catchment area. Main industries concern food processing, textile, leather and paper production and metallurgy. One fish- filleting factory showed the highest annual nutrient loads with $0.13 \mathrm{t} \mathrm{NO}_{3}-\mathrm{N}, 0.20 \mathrm{t} \mathrm{NH}_{4}-\mathrm{N}$ and $0.77 \mathrm{t} \mathrm{PO}_{4}-\mathrm{P}$, while another disposed of annual loads that amounted to $0.10 \mathrm{t} \mathrm{NH}_{4}-\mathrm{N}$ and $0.49 \mathrm{t} \mathrm{PO}_{4}-\mathrm{P}$. From food-processing industries, the highest annual load of organic matter (COD) discharged to the lake amounted to $36.8 \mathrm{t}$. A tannery in Jinja released effluent with an extremely high mean concentration of the very toxic chromium ${ }^{+6}$ of $264 \mathrm{mg} \cdot \ell^{-1}$, which results in an estimated annual load of $2.2 \mathrm{t}$ of $\mathrm{Cr}^{+6}$. Concentrations of nitrogen and phosphorus from fish-filleting industries and chromium ${ }^{+6}$ from the tannery were far above the allowed effluent limits in Uganda, leading to enhanced eutrophication and bioaccumulation of $\mathrm{Cr}^{+6}$ in Napoleon Gulf, Lake Victoria.

The study provides information on point sources of effluent derived from Jinja's industrial sector in an effort to force resource users to move towards a more sustainable pattern of environmental management. The most appropriate way to reduce the ongoing eutrophication and pollution of Lake Victoria would be to reduce the releases of nitrogen, phosphorus, organic compounds and chromium into Napoleon Gulf by on-site pretreatment, so that they remain within non-critical levels. Industries must be required to monitor their effluents before these are discharged into Kirinya National Water and Sewerage Corporation oxidation ponds and finally into Kirinya West urban wetlands.
\end{abstract}

Keywords: industrial pollution, point sources, heavy metals, potential loads, hot spots, Lake Victoria, on-site pretreatment

\section{List of abbreviations}

$\begin{array}{ll}\text { APHA } & \text { American Public Health Association } \\ \text { BOD } & \text { Biological oxygen demand } \\ \text { COD } & \text { Chemical oxygen demand } \\ \text { DO } & \text { Dissolved oxygen } \\ \text { LVEMP } & \text { Lake Victoria Environmental Management Project } \\ \text { NEMA } & \text { National Environment Management Authority } \\ \text { NWSC } & \text { National Water and Sewerage Corporation } \\ \text { SRP } & \text { Soluble reactive phosphorus } \\ \text { WHO } & \text { World Health Organisation }\end{array}$

\section{Introduction}

Lake Victoria is Africa's largest tropical freshwater lake and provides a critically important source of drinking water and fish for the rapidly growing population living in the surrounding region. The biology and limnology of Lake Victoria have been summarised recently (Bootsma and Hecky, 2003). The

* To whom all correspondence should be addressed.

正 +41 4463482 80; fax: +41 4463482 04;

e-mail: bachofen@botinst.unizh.ch

Received 20 June 2006; accepted in revised form 29 November2007. rapidly growing urban population with its increasing demand for freshwater resources and the extensive growth of agricultural and industrial activities have given rise to progressively increasing problems related to the environmental state of Lake Victoria (Ntiba et al., 2000). High nutrient inputs during the past 50 years have increased eutrophication levels in the lake, particularly in the regions along the lake shore (Hecky, 1993). Algal biomass has increased 5 times compared to 40 years ago (Mugidde, 1993) and nearly half of the lake bottom waters become anoxic for several months each year (Hecky et al., 1993).

Despite the chemical and biological changes that have been observed in Lake Victoria in the past, few water research studies have been conducted to understand the significance of these changes, or the causes of these changes, or to identify the critical factors to reduce their impacts on the lake's ecology. Regrettably, Lake Victoria is the primary recipient of industrial and municipal waste in this eastern region of Uganda. Within Jinja Municipality with its more than 72000 inhabitants, wastewater is directed into the Napoleon Gulf of Lake Victoria. The major sources of water pollution are:

- Disposal of domestic and municipal waste including garbage, excreta and liquid household waste

- Diffuse agricultural runoff containing fertilisers, pesticides and herbicides 
- Land degradation practices

- Industrial effluents.

These pollution sources have been evaluated theoretically for Lake Victoria using environmental models based on the quantities of industrial production, land use, natural purification in rivers and wetlands, and atmospheric inputs (Scheren et al., 2000). Nutrients appear to enter the lake primarily through agricultural runoff and atmospheric deposition, while organic matter originates mostly from discharges of domestic and industrial wastes (Lindenschmidt et al., 1998; Scheren et al., 2000). While diffuse pollution loads from land usage have been studied (Lindenschmidt et al., 1998), this study addresses the pollution that enters Lake Victoria from several specific industrial point sources. These can be better evaluated and controlled in comparison to undefined diffuse sources that enter the lake.

Several companies from Jinja's industrial sector discharge large volumes of untreated effluents into the rivers Nile, Walukuba and Kikenyi, as well as into Jinja's urban wetlands and into Lake Victoria. This results in nutrient enrichment, the accumulation of toxic compounds in biomass and sediments (Campell et al., 2003a; b), loss of dissolved oxygen in the water, fish kills and other nuisances. Wetlands are important in many respects: they recharge groundwater aquifers, protect the shore lines from wave action, clean polluted water and act as nutrient traps (Byamukama et al., 2000). They also assist in conserving biodiversity, e.g. by acting as a shelter and nursery area for fish. Furthermore, wetlands have served and still serve the local people as source of food and raw materials for crafts (Denny, 2001).

The Jinja wetland catchment area covers an area of between 42 to $48 \mathrm{~km}^{2}$ and contains 8 different categories of pollution point sources, including industries that produce or process chemicals, food, fish, tanning of animal skins, textiles, paper and pulp, metallurgy, and beverages. Except for Nile Breweries Ltd., which is located on the western bank of the River Nile and downstream Lake Victoria, the other point sources are all located to the east of the River Nile and along urban wetlands. Their proximity to Lake Victoria is due to the easy access to water that is needed for the many industrial production processes.

Quantitative information on human activities at point sources in the catchment area of Jinja's urban wetlands is urgently needed to identify pollution 'hot spots'. A few water quality data for tropical African inland waters are available from scattered investigations (Saad, 1987; Saad et al., 1990). However, since information on active point sources is lacking for water resource users in Jinja Town, it is difficult to distinguish the effects of point source pollution from those caused by diffuse pollution. Eutrophication of Lake Victoria via polluted water inflows and atmospheric deposition therefore continues to increase in an uncontrolled manner despite the present Ugandan legislation (NEMA, 1995) which requires efficient on-site pretreatment systems for all contaminated effluents in Uganda.

The shoreline of Lake Victoria within the Jinja Municipality boundary is bordered by the Kirinya West/Loco, Kirinya East, Masese and Budumbuli urban wetlands. These wetlands have long acted as filters for nutrients and contaminants that originate from the catchment area, thereby protecting the water quality of Lake Victoria (Kansiime and Nalubega, 2000). However, the shoreline is increasingly influenced by human activities and it is not surprising that wetland degradation has contributed to a gradual change of water quality in Lake Victoria (Verschuren et al., 2002). This can be seen as increased nutrient levels and chlorophyll- $a$ concentrations, loss of oxygen in the deeper water, the reduction of biodiversity and an increase in toxic organic compounds over the past decades (Denny, 1988; Hecky, 1993; Hecky et al., 1994; Kansiime et al., 1995; Harro, 1996; Denny, 2001; Verschuren et al., 2002).

This study concentrates on the industrial part of the town of Jinja, especially on the Kirinya West urban wetland which receives most of the domestic, municipal and industrial effluents, surface runoff and stormwater from the town. Each industrial pollutant source was assessed in terms of its location, type of inputs, production processes, economic products, by-products, and harmful effluents. It is hoped that the results will assist these industries and authorities to reach agreement on the need for effluent treatment and then to initiate on-site pretreatment and the adoption of cleaner production technologies at these industrial sites. This will contribute towards more effective multi-sectoral management of industrial effluents within Jinja Municipality and assist in improving water quality in Lake Victoria. 


\section{Materials and methods}

\section{Study area}

The study area, the industrial centre of Jinja, is located to the east of Jinja Town. Jinja Town is the second largest city in Uganda and is the industrial centre of the country, and is located $80 \mathrm{~km}$ east of the capital Kampala. The town is located at an altitude of $1230 \mathrm{~m}$ a.s.l., approximately $45 \mathrm{~km}$ north of the equator, and mean daily temperatures range between $17^{\circ} \mathrm{C}$ and $31^{\circ} \mathrm{C}$. Jinja Municipality covers an area of some $28 \mathrm{~km}^{2}$ and stretches along the northern shores of Lake Victoria (Fig. 1) where the river Nile starts its $6400 \mathrm{~km}$ journey to the Mediterranean Sea. An extensive agricultural landscape surrounds the town, including the large sugarcane plantations of Kakira Sugar Works Ltd. to the north and northwest. Jinja's riparian papyrus wetlands are located to the east of the source of River Nile and along the northern shores of the Napoleon Gulf of Lake Victoria, stretching between $33^{\circ} 10^{\prime} \mathrm{E}$ to $33^{\circ} 15^{\prime} \mathrm{E}$ and $0^{\circ} 25^{\prime} \mathrm{N}$ to $0^{\circ} 30^{\prime} \mathrm{N}$. The urban wetlands of Jinja cover areas of $0.5 \mathrm{~km}^{2}$ (Kirinya West/ Loco), $1.0 \mathrm{~km}^{2}$ (Kirinya East/Walukuba), $0.5 \mathrm{~km}^{2}$ (Masese) and $0.9 \mathrm{~km}^{2}$ (Budumbuli), respectively (Koller and Kunz, 1997).

The annual climatic cycle is divided into four seasons - two dry seasons from December to March and from July to September, each of which is followed by a rainy season between March and June and from September to November, respectively. Periods of heavy rainfall coincide with periods with intense evaporation (Jinja Municipality, 1997; Lindenschmidt et al., 1998).

\section{Sampling}

Operating factories were assessed in 1997 and 1998 during both the dry season (December 1997 to March 1998) and the rainy season (March 1998 to June 1998). Point sources were selected on the basis of their locations, types of inputs and outputs, availability of on-site wastewater treatment facilities, and the potential environmental impacts of their industrial effluents. Prior to the main sampling campaign, 23 active point sources in the industrial sector of Jinja Municipality (Table 1) were screened in a two-month preliminary survey. Using a random sampling methodology, daily in situ measurements were made of $\mathrm{DO}, \mathrm{pH}$, conductivity and temperature using calibrated field meters, a WTW oximeter for DO and temperature, a Tetracon 96A-4 meter for conductivity and a WTW $\mathrm{pH}$ meter for $\mathrm{pH}$. Two of the companies listed in Table 1, namely Sukari Sugar Ltd and Oxy-Plastic Ltd, were found not to produce wastewater. The National Water and Sewerage Corporation (NWSC) in Jinja, besides supplying drinking water to the local population and industries, also collects industrial wastewater in the Kirinya Pond as a natural wastewater treatment system. Water residence times in this pond are estimated to average $30 \mathrm{~d}$. Input/output data for freshwater and wastewater of the companies that were investigated are listed in Table 4, while their locations are shown in Fig. 1.

This study demonstrated that interviews with industrial workers and management in focus group discussions, using a structured questionnaire entitled 'Assessing the pollution status of the catchment area of Jinja's urban wetlands', were of great importance for collecting data from the industries. Questions posed to each industry concerned qualitative and quantitative information on the goods produced and raw materials used, as well as their by-products, water use, solid waste and wastewater, and wastewater management.

After the preliminary screening, industries were selected

\begin{tabular}{|c|c|c|}
\hline \multicolumn{3}{|c|}{$\begin{array}{c}\text { TABLE } 1 \\
\text { List of pollution sources of industries in the } \\
\text { Jinja catchment area }\end{array}$} \\
\hline $\begin{array}{l}\text { Type of } \\
\text { industry }\end{array}$ & Companies and industries involved & $\begin{array}{l}\text { Waste- } \\
\text { water } \\
\text { ana- } \\
\text { lysed }\end{array}$ \\
\hline Tannery & Leather Industries of Uganda & + \\
\hline Textiles & $\begin{array}{l}\text { Textile Mills (Mulco) Ltd. } \\
\text { Uganda Garments (Ugil) Ltd. }\end{array}$ & * \\
\hline Beverages & $\begin{array}{l}\text { Jubilee Ice \& Soda Works Ltd. } \\
\text { Garden Tea Ltd. }\end{array}$ & * \\
\hline $\begin{array}{l}\text { Fish } \\
\text { filleting }\end{array}$ & $\begin{array}{l}\text { Agro-Marine Fishing Co. Ltd. } \\
\text { Gomba Fishing Co. Ltd. } \\
\text { Masese (Nafco) Fishing Co. Ltd. }\end{array}$ & $\begin{array}{l}+ \\
+ \\
*\end{array}$ \\
\hline $\begin{array}{l}\text { Food } \\
\text { processing } \\
\text { except fish }\end{array}$ & $\begin{array}{l}\text { Kengrow (Iganga) Industries Ltd, } \\
\text { Kakira Sugar Works Ltd, Sukari Sugar Ltd. } \\
\text { Uganda Feeds Ltd, Uganda Bread Ltd. } \\
\text { Uganda Millers Ltd, Uganda Grain Milling } \\
\text { Co. Ltd. }\end{array}$ & $\begin{array}{l}+ \\
- \\
+ \\
-\end{array}$ \\
\hline $\begin{array}{l}\text { Pulp and } \\
\text { paper }\end{array}$ & $\begin{array}{l}\text { Associated Paper Industries Ltd. } \\
\text { Nile Plywood Ltd, Papco Industries Ltd. } \\
\text { Timber Investments Ltd, New Printpark (U) } \\
\text { Ltd. }\end{array}$ & $\begin{array}{l}- \\
- \\
-\end{array}$ \\
\hline Chemical & $\begin{array}{l}\text { Associated Match Co. Ltd. } \\
\text { Crown Tiles Ltd, British American Tobacco } \\
\text { Ltd. } \\
\text { Oxy-Plastics Ltd, March International Ltd. }\end{array}$ & $\begin{array}{l}- \\
-\end{array}$ \\
\hline Metallurgy & $\begin{array}{l}\text { Copper Smelting Co. Ltd. } \\
\text { East African Steel Co. Ltd. } \\
\text { Chillington Co. Ltd. } \\
\text { Steel Rolling Mills Ltd, Mill Tyres Ltd. } \\
\text { Uganda Metal Industries Ltd. }\end{array}$ & $\begin{array}{l} \\
* \\
+ \\
+ \\
+ \\
-\end{array}$ \\
\hline $\begin{array}{l}\text { Wastewater } \\
\text { purification }\end{array}$ & NWSC Kirinya pond & \\
\hline
\end{tabular}

All sources were screened for 2 months, then a selection was made based on flow volume, on site pre-treatment, importance of the waste, and accessibility of the wastewater

+ Point sources sampled

* Point sources not active at the time of the project

- Point sources not sampled

on the basis of their effluent flow volumes, presence or absence of on-site pretreatment, importance of the waste as a pollutant, and the relative accessibility of the sampling site for the collection of wastewater samples. Wastewater samples were collected between 9:00 and 23:00 at 30 or 60 min intervals, during 5 periods between November 1997 and June 1998. Besides single samples, time-averaged composite samples were also collected by mixing equal volumes of all samples collected at a single site during $1 \mathrm{~d}$. The wastewater samples were kept in polypropylene bottles (cleaned with dilute nitric acid and rinsed with distilled water before use) on ice in coolers at 4 to $6^{\circ} \mathrm{C}$, and protected from direct sunlight until analysis in the laboratory. Wastewater discharge volumes were estimated according to Williams (1993).

For analyses of nutrients, the samples were filtered through $0.45 \mu \mathrm{m}$ membrane filters and the samples were analysed for $\mathrm{NO}_{3}-\mathrm{N}$ (Merck Spectroquant Test Kit No. 14773), $\mathrm{NH}_{4}-\mathrm{N}$ (Merck Spectroquant Test Kit No. 14752 and Standard Methods, 1992), SRP (Merck Spectroquant Test Kit No. 14848 and Standard Methods, 1992) within 48 h of collection using standard colorimetric methods with a UVIKON 725 spectrophotometer (Kontron instruments). The COD and the BOD concentrations in wastewater samples were determined from unfiltered samples after appropriate dilution (Merck Spectroquant Test Kit No. 


\begin{tabular}{|c|c|c|c|c|c|}
\hline \multicolumn{6}{|c|}{$\begin{array}{l}\text { TABLE } 2 \\
\text { Characterisation and description of mass flow for selected food processing industries }\end{array}$} \\
\hline Company & Raw materials & $\begin{array}{l}\text { Production } \\
\text { processes }\end{array}$ & Economic products & By-products & $\begin{array}{l}\text { Hazardous compounds } \\
\text { in effluent }\end{array}$ \\
\hline $\begin{array}{l}\text { Agro- } \\
\text { Marine } \\
\text { Ltd. }\end{array}$ & $\begin{array}{l}\text { Fish }\left(30 \mathrm{t} \cdot \mathrm{d}^{-1} \mathrm{Nile}\right. \\
\text { perch, depending on } \\
\text { catch }), \mathrm{NWSC} \text { water } \\
\left(30-175 \mathrm{~m}^{3} \cdot \mathrm{d}^{-1}\right) \\
6 \% \text { chlorine water, } \\
\mathrm{NaOCl} \& \mathrm{Al}_{2}\left(\mathrm{SO}_{4}\right)_{3} \text {, } \\
\text { lake water }\end{array}$ & $\begin{array}{l}\text { cleaning, filleting, } \\
\text { packaging, ship- } \\
\text { ping (local \& } \\
\text { international) }\end{array}$ & $\begin{array}{l}\text { Frozen fish fillets, head- } \\
\text { less gutted fish, } \\
\text { head on without gills } \\
\left(6 \mathrm{t} \cdot \mathrm{d}^{-1}\right) \\
\text { Ice cubes \& flecks }\end{array}$ & $\begin{array}{l}\text { Off-cuts, trim- } \\
\text { mings, fats, scales, } \\
\text { skins, heads, } \\
\text { bladders, whole } \\
\text { fish rejects }\end{array}$ & $\begin{array}{l}\text { Fresh blood and by- } \\
\text { products in wastewater } \\
\text { Note: } \\
\text { oxidation pond not } \\
\text { operating }\end{array}$ \\
\hline $\begin{array}{l}\text { Gomba } \\
\text { Fishing } \\
\text { Industries } \\
\text { Ltd. }\end{array}$ & $\begin{array}{l}\text { Fish }\left(20-30 \mathrm{t} \cdot \mathrm{d}^{-1}\right. \\
\text { average Nile perch) } \\
\text { water }(\text { minimum } \\
\left.110 \mathrm{~m}^{3} \cdot \mathrm{d}^{-1}\right), \\
\text { water for ice plant }(20 \\
\left.-30 \mathrm{~m}^{3} \cdot \mathrm{d}^{-1}\right) \text {, } \\
\text { chlorinated water }\end{array}$ & $\begin{array}{l}\text { cleaning, fillet- } \\
\text { ing, packaging, } \\
\text { shipping (local \& } \\
\text { international) }\end{array}$ & $\begin{array}{l}\text { Frozen fish fillets, fresh } \\
\text { or chilled fish fillets, } \\
\text { fish meal, dried gall } \\
\text { bladders, } \\
\text { ice flakes, ice blocks } \\
\left(50 \mathrm{~m}^{3}\right) \text {, } \\
\text { tanned Nile perch } \\
\text { skins, products of Nile } \\
\text { perch skins }\end{array}$ & $\begin{array}{l}\text { Off-cuts, trim- } \\
\text { mings, fats, scales, } \\
\text { skins, heads, whole } \\
\text { fish rejects }\end{array}$ & $\begin{array}{l}\text { Fresh blood and by- } \\
\text { products in wastewater, } \\
\text { Note: } \\
\text { Wastewater purification } \\
\text { by sand-filtration, aera- } \\
\text { tion, sedimentation } \\
\mathrm{Cr}_{2}\left(\mathrm{SO}_{4}\right)_{3} \text { \& CaO from } \\
\text { fish-skin tannery }\end{array}$ \\
\hline $\begin{array}{l}\text { Kengrow } \\
\text { Industries } \\
\text { Ltd. }\end{array}$ & $\begin{array}{l}\text { Seeds of cotton, } \\
\text { sesame, sunflower } \\
\left(10 t \cdot d^{-1}\right), \\
\text { fatty acids, KOH, } \\
\text { dyes, perfumes, palm } \\
\text { oil, sodium silicate, } \\
\text { NWSC water and } \\
\text { borehole water }\end{array}$ & $\begin{array}{l}\text { cleaning, crushing } \\
\text { seeds, } \\
\text { oil refining, } \\
\text { neutralisation, } \\
\text { bleaching, } \\
\text { filtration, } \\
\text { saponification } \\
\text { burning seed husks } \\
\text { (as fuel) }\end{array}$ & $\begin{array}{l}\text { raw soap }\left(5 \mathrm{t}^{-1} \mathrm{~d}^{-1}\right) \\
\text { Silver Shine blue } \\
\text { laundry soap ( } 875 \text { bars } \\
\left.\text { day }^{-1}\right) \text {. } \\
\text { steam, hot water }\end{array}$ & $\begin{array}{l}\text { Cotton seed cake, } \\
\text { seed ash \& dust } \\
\text { Cotton seed husks, } \\
\text { as animal food or } \\
\text { burned for heat } \\
\text { unrefined oil }\end{array}$ & $\begin{array}{l}\text { Thick oily and soapy } \\
\text { wastewater, released at } \\
\text { night, oil, soap and seed } \\
\text { spillage, seed dust, bad } \\
\text { odors from stored waste, } \\
\text { heat }\end{array}$ \\
\hline $\begin{array}{l}\text { Uganda } \\
\text { Bread } \\
\text { Ltd. }\end{array}$ & $\begin{array}{l}\text { Wheat flour (300 kg } \\
\left.\text { batch }^{-1}\right) \text {, baking fat, } \\
\text { yeast, acetic acid, } \\
\text { sugar, salt, NWSC } \\
\text { water }\left(28 \mathrm{~m}^{3}\right. \\
\left.\text { day }^{-1}\right) \\
\\
\text { boiler oil, } \\
\text { liquid detergent }\end{array}$ & $\begin{array}{l}\text { mixing, } \\
\text { fermentation } \\
\text { oven baking, } \\
\text { slicing }\end{array}$ & $\begin{array}{l}\text { family \& ordinary } \\
\text { bread, scones }\end{array}$ & $\begin{array}{l}\text { damaged \& } \\
\text { returned bread } \\
\left(250 \mathrm{~kg}_{\text {day }}^{-1}\right) \text {, } \\
\text { unfermented } \\
\text { dough } \\
\text { hot water }\end{array}$ & $\begin{array}{l}\text { unburned bread, } \\
\text { oily wastewater, } \\
\text { heat }\end{array}$ \\
\hline $\begin{array}{l}\text { Sukari } \\
\text { Sugar } \\
\text { Ltd. }\end{array}$ & $\begin{array}{l}\text { Ordinary sugar (local, } \\
\left.9 \text {-10 tonnes day }{ }^{-1}\right), \\
\text { aspartame concen- } \\
\text { trate (imported) } \\
\text { NWSC water }(2-18 \\
\left.\mathrm{m}^{3} \text { day }^{-1}\right)\end{array}$ & $\begin{array}{l}\text { blending, } \\
\text { packaging, selling }\end{array}$ & $\begin{array}{l}\text { Sukari sweet sugar } \\
\left(9-10 t \cdot d^{-1}\right)\end{array}$ & $\begin{array}{l}\text { None } \\
\text { (factory in practice } \\
\text { operating with } \\
\text { clean technology) }\end{array}$ & none \\
\hline
\end{tabular}

Data presented were obtained from questionnaires and site visits

14555 and Standard Methods, 1992). For metal determinations (copper, nickel, chromium, lead, cadmium and manganese), unfiltered wastewater was digested in concentrated nitric acid (5:1) under reflux for $1 \mathrm{~h}$ and, after cooling, filtered through 0.45 $\mu \mathrm{m}$ membrane filters (Standard Methods, 1992). Metal determinations were done at the Geology Department, Makerere University, Kampala, by atomic absorption spectrophotometry (AAS)(Perkin-Elmer 2380 AAS). Instrument calibration was obtained with standards of the metals, including internal standards to avoid matrix effects.

Statistical analyses were performed with the statistical package available in Microsoft-Excel.

Results from group discussions, interviews and other information were grouped and the protocols were analysed with regard to effluent inputs, outputs, and processes to supplement the analytical data on the point sources.

\section{Results}

Based on the preliminary survey with the parameters temperature, $\mathrm{pH}$, conductivity and $\mathrm{DO}$, the selection of sampling sites was based on:

- Type of industry

- Volume of waste output

- Accessibility

- Daily operation for 12 or $24 \mathrm{~h}$, respectively

- Information from discussions with executives of the company. 


\begin{tabular}{|c|c|c|c|c|c|}
\hline \multicolumn{6}{|c|}{$\begin{array}{r}\text { TABLE } 3 \\
\text { Characterisation and description of mass flo }\end{array}$} \\
\hline $\begin{array}{l}\text { Com- } \\
\text { pany }\end{array}$ & Raw materials & $\begin{array}{l}\text { Production } \\
\text { processes }\end{array}$ & $\begin{array}{l}\text { Economic } \\
\text { products }\end{array}$ & By-products & $\begin{array}{l}\text { Hazardous } \\
\text { compounds in } \\
\text { effluents }\end{array}$ \\
\hline $\begin{array}{l}\text { Steel } \\
\text { Rolling } \\
\text { Co. Ltd. }\end{array}$ & 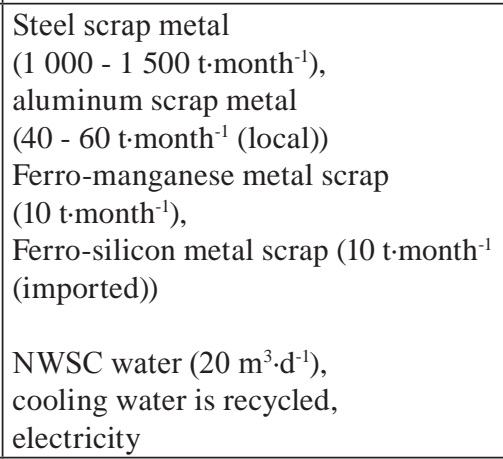 & \begin{tabular}{|l} 
melting, \\
casting, \\
rolling, \\
stretching, \\
power bending \\
grading, \\
quality control
\end{tabular} & $\begin{array}{l}\text { round, square and } \\
\text { twisted steel bars } \\
\text { of various dimen- } \\
\text { sions }\end{array}$ & $\begin{array}{l}\text { slag, } \\
\text { steel metal cut- } \\
\text { tings (to be } \\
\text { recycled), } \\
\text { poisonous gases } \\
\left(\mathrm{CO}, \mathrm{H}_{2} \mathrm{~S}\right)\end{array}$ & $\begin{array}{l}\text { wastewater } \\
\text { containing heavy } \\
\text { metals, oil films } \\
\text { on wastewater, } \\
\text { slag containing } \\
\text { metal, dust and } \\
\text { fumes }\end{array}$ \\
\hline $\begin{array}{l}\text { Chilling- } \\
\text { ton Tool } \\
\text { Co. Ltd. }\end{array}$ & $\begin{array}{l}\text { Steel flat bars }\left(200 \mathrm{t} \cdot \mathrm{month}^{-1}\right) \\
\text { metal pipes, metal straps, mild steel } \\
\text { sheets, paint, vanish, xylene } \\
\text { machete blanks, timber off cuts, } \\
\text { grease \& oil lubricants } \\
\text { NWSC water }\left(14 \mathrm{~m}^{3} \cdot \mathrm{d}^{-1}\right)\end{array}$ & $\begin{array}{l}\text { many production } \\
\text { processes such as } \\
\text { cutting, shearing, } \\
\text { furnace heat- } \\
\text { ing, squeezing, } \\
\text { pressing, ribbing, } \\
\text { rolling, spreading, } \\
\text { chopping, holing, } \\
\text { marking, finishing }\end{array}$ & $\begin{array}{l}\text { hand hoes } \\
\text { assorted } \\
\left(6000 \cdot d^{-1}\right) \\
\text { wheelbarrows, } \\
\text { slashers }\end{array}$ & $\begin{array}{l}\text { Scrap metal ( } 28 \\
\text { t·month-1), } \\
\text { metal chips, } \\
\text { hoe trimmings } \\
\text { metal dust, } \\
\text { burnt furnace oil, } \\
\text { fumes of oxides of } \\
\text { iron, copper and } \\
\text { organic solvents }\end{array}$ & $\begin{array}{l}\text { wastewater } \\
\text { containing heavy } \\
\text { metals, oil films } \\
\text { on wastewater, } \\
\text { metal containing } \\
\text { slag, dust and } \\
\text { fumes, heat, } \\
\text { poisonous gases }\end{array}$ \\
\hline $\begin{array}{l}\text { Leather } \\
\text { Indus- } \\
\text { tries of } \\
\text { Uganda }\end{array}$ & $\begin{array}{l}\text { Fresh cow and goat skins (550 kg } \\
\text { day }{ }^{-1} \text { ) } \\
\text { Chemicals: chromosol, acetic acid, } \\
\text { sulphuric acid, sodium carbonate, } \\
\text { ammonium sulphate, sodium bisul- } \\
\text { phite, sodium chloride, chromium } \\
\text { sulphate, caustic soda, sodium sul- } \\
\text { phide, lime, sodium sulphate } \\
\text { aluminum sulphate, calcium hydrox- } \\
\text { ide \& manganese sulphate for precipi- } \\
\text { tation \& desludging } \\
\text { NWSC water }\left(15 \mathrm{~m}^{3} \mathrm{day}^{-1}\right) \text {, } \\
\text { lake water }\left(10 \mathrm{~m}^{3} \mathrm{day}^{-1}\right)\end{array}$ & $\begin{array}{l}\text { weighing, } \\
\text { salting, } \\
\text { soaking, } \\
\text { liming, } \\
\text { tanning } \\
\text { desludging, } \\
\text { deliming, } \\
\text { precipitation, } \\
\text { packaging, } \\
\text { selling (export) }\end{array}$ & $\begin{array}{l}\text { Semi finished } \\
\text { leather, wet } \\
\text { blue cow \& goat } \\
\text { leather, finished } \\
\text { leather } \\
\text { bicycle seats, } \\
\text { bags, belts, shoes }\end{array}$ & $\begin{array}{l}\text { Sodium sulphide, } \\
\text { chrome cake, } \\
\text { lime sludge cake, } \\
\text { fleshings }\end{array}$ & $\begin{array}{l}\text { Note: } \\
\text { aeration of oxida- } \\
\text { tion ponds, bad } \\
\text { \& toxic odors of } \\
\text { NH3 \& H2S, } \\
\text { volatile organics } \\
\text { on-site in-filling } \\
\text { of chrome cake }\end{array}$ \\
\hline $\begin{array}{l}\text { Oxy- } \\
\text { Plastics } \\
\text { Ltd. }\end{array}$ & $\begin{array}{l}\text { High density polyethylene for blow } \\
\text { and injection molding, } \\
\text { low density polyethylene } \\
\text { water }\left(1.7 \mathrm{~m}^{3} \text { day }^{-1}\right)\end{array}$ & $\begin{array}{l}\text { mixing, heating, } \\
\text { cooling, } \\
\text { remelting poly- } \\
\text { thene granules, } \\
\text { recycling plastic } \\
\text { trimmings }\end{array}$ & $\begin{array}{l}\text { Plastic jerry cans, } \\
\text { plates, mugs, } \\
\text { pharmaceutical } \\
\text { and laboratory } \\
\text { plastic ware }\end{array}$ & $\begin{array}{l}\text { Plastic trimmings, } \\
\text { organic gases } \\
\text { (CxHy), } \\
\text { steam }\end{array}$ & $\begin{array}{l}\text { Note: } \\
\text { not active }\end{array}$ \\
\hline
\end{tabular}

Data presented were obtained from questionnaires and site visits

All of the surveyed companies are listed in Table 1; the ones selected for further analysis are characterised in Tables 2 and 3 , based on interviews and on-site discussions. These tables provide approximate quantities of the materials' flow through the production processes of the various types of industries, and illustrate the large variety of usable or waste by-products and polluting compounds that are present in the wastewater. Wastes from food-processing activities consist mainly of organic substances, such as blood, fat, skins, bones, or other residues from grain and bread processing. The tannery of fish and cattle skins results in wastewater containing chromium. Effluents from metal or chemical industries contain hazardous compounds, mainly heavy metals, gases, as well as dust and waste heat. Table 4 illustrates the daily water use and wastewater discharge volumes, demonstrating that food-processing industries clearly produce larger quantities of solid waste and wastewater than metal and chemical industries and these can be expected to pollute the wetlands and the water of Lake Victoria. The NWSC Kirinya Pond acts as an oxidation pond (purification pond) for the city of Jinja and most of the industries of the area; the average volume of its wastewater discharge to Lake Victoria is approximately 15 times the sum of the industries monitored in this project.

The daily time course of the on-site measurements of the physical parameters indicate that the concentrations and loads of polluting compounds vary during the day; in many cases this variation can be very wide. This is best seen in the mean values with the corresponding standard deviation (from between 11 and 40 sampling data points, Table 5). As expected, the 
outflow of the large NWSC purification pond has a considerable buffering capacity. Parameters related to primary production showed almost constant values for the 4 parameters temperature, $\mathrm{pH}$, conductivity and $\mathrm{DO}$, and the values of these parameters in the effluent from the NWSC pond were very similar to those measured in the swamps and the open water of Lake Victoria (Lindenschmidt et al., 1998; Campell et al., 2003). Effluent temperatures ranged quite widely, between 20 to $35^{\circ} \mathrm{C}$, indicating either the use of hot water (Steel Mill, Kengrow Industries Ltd, a food processing factory, and the leather industry) or of ice (Gomba Fishing and Agro-Marine), since the temperature in the lake water remains within 23 and $27^{\circ} \mathrm{C}$ during the year (Lindenschmidt et al., 1998; Campell et al., 2003). The $\mathrm{pH}$ values were mostly neutral to slightly alkaline, except for effluents from the Kengrow and leather industries where mean $\mathrm{pH}$ values increased to around $\mathrm{pH}$ 9.9, with peak values up to $\mathrm{pH} 11$. Conductivity, used as a measure of the concentration of total dissolved salts, varied considerably in wastewater from food processing, ranging between 100 and $400 \mu \mathrm{S} \cdot \mathrm{cm}^{-1}$, except during those times when the facility was being cleaned. In contrast, wastewater from the leather industry as well as from Kengrow showed peaks of waste release with values reaching $70 \mathrm{mS} \cdot \mathrm{cm}^{-1}$; this resulted in standard deviations that were larger than the corresponding mean values. The tanning industry uses large amounts of ammonium sulphate, calcium oxide, sodium chloride and sodium sul-

\begin{tabular}{|c|c|c|}
\hline \multicolumn{3}{|c|}{ 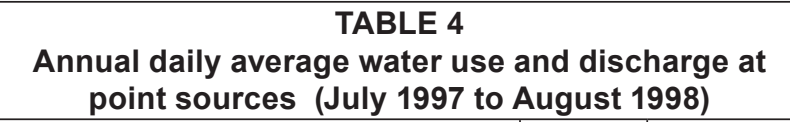 } \\
\hline Company & $\begin{array}{l}\text { Water } \\
\text { use } \\
\left(\mathrm{m}^{3} \cdot \mathrm{d}^{-1}\right)\end{array}$ & $\begin{array}{c}\text { waste- } \\
\text { water } \\
\text { discharge } \\
\left(\mathrm{m}^{3} \cdot \mathrm{d}^{-1}\right) \\
\end{array}$ \\
\hline Agro-Marine Export Processing Co. Ltd. & 123 & 95 \\
\hline Chillington Tool Co. Ltd. & 14 & 10 \\
\hline Gomba Fishing Industries Ltd. & 176 & 136 \\
\hline Kengrow Industries Ltd. & 23 & 17 \\
\hline Leather Industries of Uganda & 17 & 13 \\
\hline Steel Rolling Co. Ltd. & 9 & 6 \\
\hline Uganda Bread Ltd. & 28 & 21 \\
\hline NWSC Wastewater Kirinya pond & 5754 & 4443 \\
\hline
\end{tabular}

phide for the process. The steel industry (Chillington; Steel Rolling Mills) showed only small changes in all parameters. Fish processing results in high organic loads, and it is therefore not surprising that the DO concentration had practically dropped to zero at one sampling site in the factory oxidation pond (Gomba 2). In addition, the leather Industry produces high organic loads that also diminish DO concentrations in water; this also holds true for the wastewater from the Kengrow and Uganda Bread bakery. Variations in all parameters were similar during the day and night samplings at industries that operated continuously over a $24 \mathrm{~h}$ period.

Pollution loads into the wetlands and Lake Victoria from the different sources were estimated for the nutrients nitrogen and phosphorus, while COD and BOD were used as surrogate measures for organic carbon (Table 6).

While the latter parameters are low in the effluent from the NWSC pond, they are high in effluents from food- and hideprocessing industries, with average COD values exceeding $3800 \mathrm{mg} \cdot \ell^{-1}$, with occasional extreme values up to $19000 \mathrm{mg} \cdot \ell^{-1}$ for Kengrow (Fig. 2c), and $500 \mathrm{mg} \cdot \ell^{-1}$ for the leather industry. For wastes from fish processing, the COD concentrations ranged between 65 and $825 \mathrm{mg} \cdot \ell^{-1}$, with a mean of $222 \pm 168 \mathrm{mg} \cdot \ell^{-1}$ for Agro-Marine and a mean of $177 \pm 110 \mathrm{mg} \cdot \ell^{-1}$ (ranging between 40 and $670 \mathrm{mg} \cdot \ell^{-1}$ ) for Gomba fish processing (Table 6). Rapidly biodegradable carbon, as represented by the $\mathrm{BOD}_{5}$ values, was also high in wastewater from Kengrow and leather industry with a mean of 475 and $140 \mathrm{mg} \cdot \ell^{-1}$, respectively. Food-processing industries had also high levels of nitrogen compounds; surprisingly, the highest values for ammonia were found in the efflux from the NWSC wastewater pond into the wetlands. Sources of soluble phosphorus were mainly the fish, food and leather industries, while the steel industry plant contributed negligible quantities of soluble reactive phosphorus.

Concentrations of heavy metals in wastewater were generally low with the exception of the leather industry, where chromium is used in the tannery process. The presence of manganese in metallurgic wastewater was expected. The high value from Uganda Bread, which exceeded the guidelines, originated from sources that were located outside the bread bakery. Table 6 also lists the guidelines of the World Health Organisations (WHO, 2004) and the standards for discharge of effluents in Uganda (1995) for comparison.

Figure 2 illustrates the very high variations recorded in the concentrations of some selected parameters. The temperature

\begin{tabular}{|l|l|l|l|l|}
\hline \multicolumn{5}{|c|}{ TABLE 5 } \\
Mean values and standard deviation of physical parameters at wastewater outlet (number of measurements)
\end{tabular}




\begin{tabular}{|c|c|c|c|c|}
\hline \multicolumn{5}{|c|}{$\begin{array}{c}\text { TABLE } 6 \\
\text { Summary of selected chemical parameters at point } \\
\text { of discharge in relation to the standards of } \\
\text { discharge of effluents in Uganda, and WHO, } 1984 \\
\text { drinking water guidelines. All values in } \mathrm{mg} \cdot \mathrm{e}^{-1} \text {. } \\
\text { Mean values and standard deviation was } \\
\text { calculated from at least } 20 \text { samplings. }\end{array}$} \\
\hline $\begin{array}{l}\text { Selected } \\
\text { parameters }\end{array}$ & \begin{tabular}{|l|}
$\begin{array}{l}\text { Industries } \\
\text { involved }\end{array}$ \\
\end{tabular} & Mean values & WHO" & +Uganda \\
\hline \multirow[t]{2}{*}{$\begin{array}{l}\text { Chemical } \\
\text { oxygen } \\
\text { demand } \\
\text { (COD) }\end{array}$} & $\begin{array}{l}\text { Agro-Marine } \\
\text { Gomba } \\
\text { Kengrow } \\
\text { Leather } \\
\end{array}$ & $\begin{array}{c}222 \pm 168 \\
177 \pm 110 \\
3877 \pm 5024 \\
506 \pm 664\end{array}$ & \multirow[t]{2}{*}{-} & \multirow[t]{2}{*}{100} \\
\hline & NWSC pond & $14 \pm 5$ & & \\
\hline \multirow[t]{2}{*}{$\begin{array}{l}\text { Biological } \\
\text { oxygen } \\
\text { demand } \\
\left(\mathrm{BOD}_{5}\right)\end{array}$} & $\begin{array}{l}\text { Agro-Marine } \\
\text { Gomba } \\
\text { Kengrow } \\
\text { Leather } \\
\end{array}$ & $\begin{array}{c}61 \pm 71 \\
398 \pm 179 \\
475 \pm 155 \\
140 \pm 74 \\
\end{array}$ & \multirow[t]{2}{*}{-} & \multirow[t]{2}{*}{50} \\
\hline & NWSC pond & $30 \pm 12$ & & \\
\hline \multirow[t]{2}{*}{$\begin{array}{l}\mathrm{NH}_{4}^{-} \\
\text {nitrogen }\end{array}$} & $\begin{array}{l}\text { Agro-Marine } \\
\text { Gomba } \\
\text { Leather }\end{array}$ & $\begin{array}{c}2.6 \pm 1.2 \\
6.0 \pm 12.3 \\
6.4 \pm 4.9 \\
\end{array}$ & \multirow[b]{3}{*}{-} & \multirow[b]{3}{*}{10} \\
\hline & NWSC pond & $10.8 \pm 2.3$ & & \\
\hline $\begin{array}{l}\mathrm{NO}_{3}^{-}- \\
\text {nitrogen }\end{array}$ & $\begin{array}{l}\text { Agro-Marine } \\
\text { Bread } \\
\text { Kengrow } \\
\text { Leather }\end{array}$ & $\begin{array}{c}10.8 \pm 2.3 \\
4.8 \pm 4.8 \\
6.7 \pm 8.0 \\
7.8 \pm 4.4\end{array}$ & & \\
\hline $\begin{array}{l}\text { Soluble } \\
\text { reactive } \\
\text { phosphorus }\end{array}$ & $\begin{array}{l}\text { Agro-Marine } \\
\text { Kengrow } \\
\text { Leather } \\
\text { Steel Rolling } \\
\text { NWSC pond }\end{array}$ & $\begin{array}{c}11.5 \pm 5.6 \\
5.5 \pm 4.5 \\
1.5 \pm 1.2 \\
0.03 \pm 0.04 \\
2.4 \pm 1.1\end{array}$ & - & 5 \\
\hline $\begin{array}{l}\text { Copper } \\
\text { (Cu) }\end{array}$ & $\begin{array}{l}\text { Bread } \\
\text { Chillington } \\
\text { Steel Rolling } \\
\text { NWSC pond } \\
\end{array}$ & $\begin{array}{c}0.03 \pm 0.02 \\
0.13 \pm 0.13 \\
0.23 \pm 0.05 \\
<0.01\end{array}$ & 2.0 & 1.0 \\
\hline $\begin{array}{l}\text { Chromium } \\
\text { (Cr) }\end{array}$ & $\begin{array}{l}\text { Bread } \\
\text { Leather } \\
\text { Chillington } \\
\text { Steel Rolling } \\
\text { NWSC pond } \\
\end{array}$ & $\begin{array}{c}0.22 \pm 0.06 \\
264 \pm 499 \\
0.15 \pm 0.03 \\
0.26 \pm 0.03 \\
<0.02 \\
\end{array}$ & $0.05^{*}$ & 0.05 \\
\hline Lead (Pb) & \begin{tabular}{|l|} 
Bread \\
Chillington \\
Steel Rolling \\
NWSC pond \\
\end{tabular} & $\begin{array}{c}0.05 \pm 0.1 \\
0.03 \pm 0.06 \\
\quad<0.05 \\
<0.02 \\
\end{array}$ & 0.01 & 0.1 \\
\hline $\begin{array}{l}\text { Manganese } \\
\text { (Mn) }\end{array}$ & $\begin{array}{l}\text { Bread } \\
\text { Chillington } \\
\text { Steel Rolling } \\
\text { NWSC pond } \\
\end{array}$ & $\begin{array}{c}0.91 \pm 0.71 \\
0.37 \pm 0.41 \\
0.28 \pm 0.04 \\
<0.02\end{array}$ & 0.4 & 1.0 \\
\hline Nickel (Ni) & 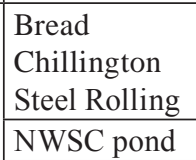 & $\begin{array}{c}0.22 \pm 0.07 \\
0.10 \pm 0.01 \\
0.30 \pm 0.03 \\
<0.02\end{array}$ & $0.02 *$ & 1.0 \\
\hline
\end{tabular}

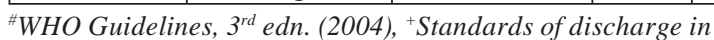
Uganda (1999), * Provisional values.

of the NWSC effluent follows the ambient temperature of the site. In contrast, fish-filleting industries (Gomba) need refrigerators and use ice, therefore the mean effluent temperature is always lower than NWSC; a sudden drop in effluent temperature to $15^{\circ} \mathrm{C}$ demonstrates the disposal of a large batch of cold water or melted ice. In contrast, the temperature of the effluent
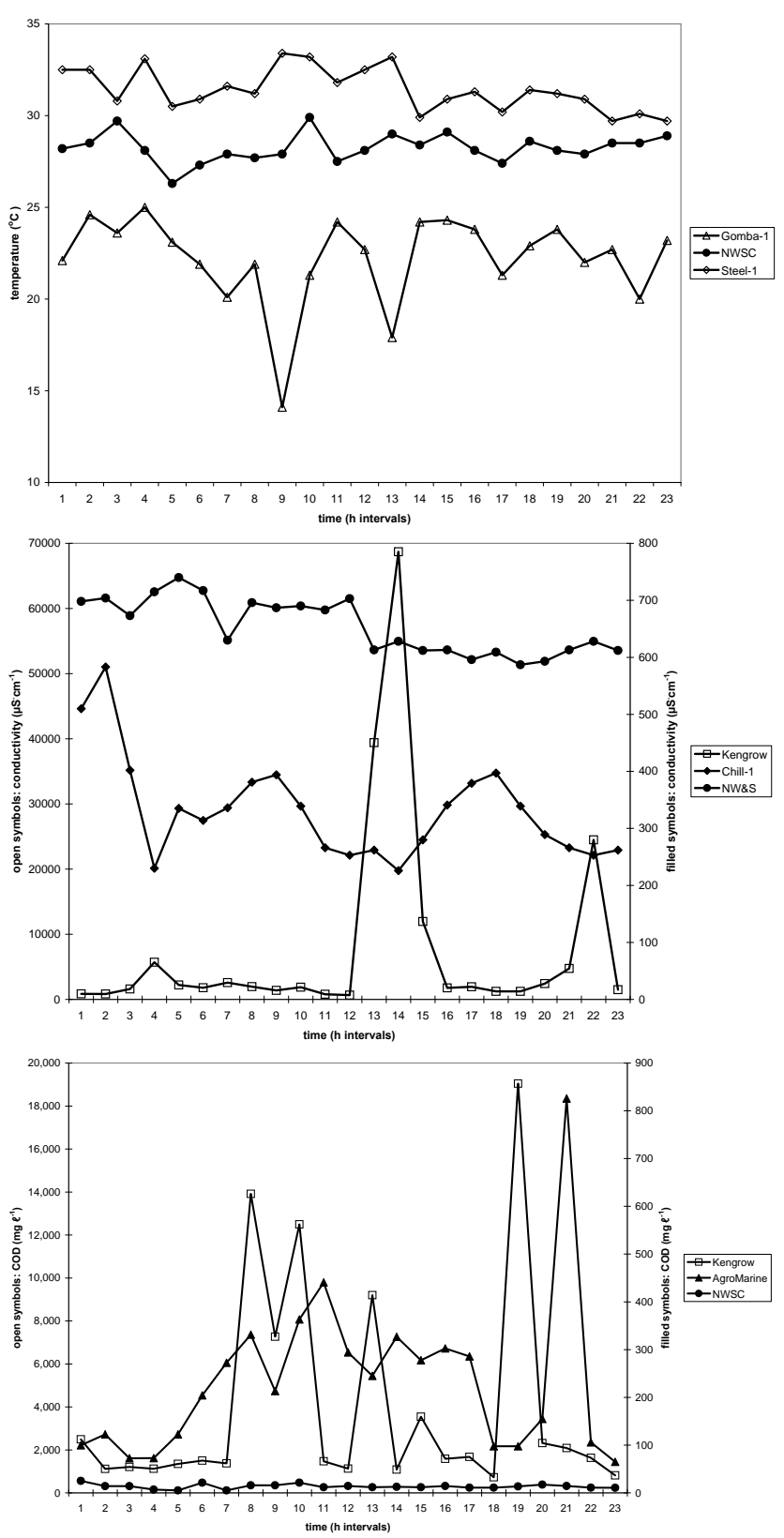

Figure 2

Time course of selected parameters at selected point sources. Measurements in intervals of one hour, plotted consecutively from different sampling days. a) temperature $\left({ }^{\circ} \mathrm{C}\right)$

b) conductivity $\left(\mathrm{HS} \cdot \mathrm{Cm}^{-1}\right)$

c) $\operatorname{COD}\left(m g \cdot \ell^{-1} \mathrm{O}_{2}\right)$

For each sampling site several individual measuring periods over 12 months in 1997/98 are presented in sequence. Sampling occurred between $8 \mathrm{am}$ and $10 \mathrm{pm}$. Due to the distances between the sampling sites, the samplings were at different dates and times, thus the curves in the graphs cannot be time correlated.

from metal industries (Steel Rolling Mills) is always higher than the water temperatures in the NWSC pond. The effluent of the NWSC pond has an average conductivity of 600 to $700 \mu \mathrm{S} \cdot \mathrm{cm}^{-1}$, with little variation, and depends mostly on the variable inputs of effluents from the different industries. In the metal industry (Chillington), conductivity values were rather low, ranging between 300 to $500 \mu \mathrm{S} \cdot \mathrm{cm}^{-1}$. The conductivity values of effluent from the food-processing plant operated by Kengrow are normally between 500 to $2000 \mu \mathrm{S} \cdot \mathrm{cm}^{-1}$, though very high values up to $70000 \mu \mathrm{S} \cdot \mathrm{cm}^{-1}$ were recorded from time to time. The precise 
TABLE 7

Estimation of annual pollution load from different point sources from industries in Jinja (kg: $\left.\mathrm{yr}^{-1}\right)$

\begin{tabular}{|c|c|c|c|c|c|c|c|c|}
\hline Chemical compound & $\begin{array}{c}\text { Agro } \\
\text { Marine }\end{array}$ & $\begin{array}{l}\text { Gomba } \\
\text { Fishing }\end{array}$ & $\begin{array}{l}\text { Kengrow } \\
\text { Industries }\end{array}$ & $\begin{array}{l}\text { Uganda } \\
\text { Bread }\end{array}$ & $\begin{array}{c}\text { Steel } \\
\text { Rolling }\end{array}$ & $\begin{array}{c}\text { Chillington } \\
\text { Co. Ltd. }\end{array}$ & $\begin{array}{c}\text { Leather } \\
\text { Industries }\end{array}$ & $\begin{array}{c}\text { NWSC } \\
\text { Kirinya } \\
\text { pond }\end{array}$ \\
\hline Nitrogen $\mathrm{NO}_{3}-\mathrm{N}$ & * & 133 & $*$ & 32.1 & 15.3 & 0.2 & 26 & 84260 \\
\hline Nitrogen $\mathrm{NH}_{4}-\mathrm{N}$ & 98 & 197 & 29 & 1.3 & 0.2 & 0.5 & 19 & 16750 \\
\hline Phosphorus (SRP) $\mathrm{PO}_{4}-\mathrm{P}$ & 485 & 774 & 48 & 1.1 & 0.1 & 0.4 & 4 & 3885 \\
\hline BOD & 2700 & 14490 & 4000 & 162 & 14.2 & 14.8 & 365 & 48530 \\
\hline COD & 10850 & 5630 & 36790 & $*$ & $*$ & $*$ & 745 & 22170 \\
\hline Copper & $*$ & $*$ & $*$ & 0.4 & 1.4 & 0.6 & $*$ & 1.6 \\
\hline Nickel & * & $*$ & $*$ & 1.5 & 1.7 & 0.4 & $*$ & $*$ \\
\hline Chromium & * & * & * & 2.1 & 1.5 & 0.5 & 2’170 & 3.2 \\
\hline Lead & * & $*$ & $*$ & 1.6 & 0.4 & 0.2 & $*$ & 16.0 \\
\hline Cadmium & $*$ & $*$ & $*$ & 0.1 & $*$ & $*$ & $*$ & $*$ \\
\hline Manganese & $*$ & * & * & 10.0 & 1.6 & 1.8 & $*$ & * \\
\hline
\end{tabular}

Loads were calculated from concentrations of mixed samples (equal volumes every hour for $12 \mathrm{~h} \cdot \mathrm{d}^{-1}$ )

$*=$ not calculated because the concentrations determined were below or at the detection limit.

cause of this variation is not known but it is probably due to the effect of periodic cleaning of the processing unit.

From the amounts of wastewater disposed and the concentrations of the various chemical parameters determined in the different effluent streams, estimates were made of the annual loads of waste compounds deposited in the wetlands and Lake Victoria. These loads are summarised in Table 7. Gomba Fishing Industries Ltd. with its inefficient treatment pond showed much higher nutrient loads for nitrogen and phosphorus when compared with Agro-Marine. Kengrow Industries Ltd., a foodprocessing factory that discharges oily and soapy effluents and lacks any on-site effluent pretreatment, discharged the highest organic load of $36.8 \mathrm{t} \cdot \mathrm{yr}^{-1}$ of organic carbon equivalents measured as COD. Leather Industries of Uganda discharged an estimated amount of $2.2 \mathrm{t} \cdot \mathrm{yr}^{-1}$ of highly toxic $\mathrm{Cr}^{+6}$. The measured chromium concentrations exceeded the maximum permissible limit of $0.05 \mathrm{mg} \cdot \ell^{-1} \mathrm{Cr}^{+6}$ by a factor of more than 5000 . In contrast, the metallurgy point sources of Steel Rolling Mills and Chillington released only small traces of the metals Copper, Lead, Nickel, Cadmium and Manganese. The concentrations that were measured in effluents were all below the maximum permissible limits. The Kirinya maturation pond, part of the NSWC public sewer and linked with the urban drainage system, contributed high loads of nutrients that will certainly contribute to the eutrophication of Lake Victoria. The final effluent discharged from the NSWC pond contributed $3.9 \mathrm{t}^{\mathrm{yr}} \mathrm{r}^{-1}$ of phosphorus and $85 \mathrm{t} \cdot \mathrm{yr}^{-1}$ of nitrogen into Kirinya West urban wetland during an annual cycle.

\section{Discussion}

Chemical pollution and high inflowing nutrient loads from increasing effluent discharges from urban centres along the lake shore are the main environmental factors leading to the degradation of Lake Victoria, an extremely important source of food and water for about $28 \times 10^{6}$ people (Ogada et al., 2004). Industries producing wastewater are situated in towns bordering the lake; in Uganda, these are mainly from Kampala and Jinja. Industrial wastewater treatment plants are generally lacking in Uganda and wastewater is drained into the wetlands (Scheren et al., 2000). The various point sources originating in industries close to the wetlands of Lake Victoria pose a strong pollution impact upon the water quality of the lake. The two fish-filleting companies released fresh fish remains and blood into their waste effluents; while the wastewater from Steel Rolling Mills had high salt concentrations, contained slag particles and had elevated temperature. Chillington discharged water that was enriched in salts in addition to metal oxide fumes, gases, heat, and oily wastes. The disposal of toxic chromium by the leather industries is very harmful, as well as the release of volatile organic compounds and toxic hydrogen sulphide. All of these industries had effluents that contained polluting compounds in concentrations well above the allowed values. Leather industries discharged peaks of up to $1250 \mathrm{mg} \cdot \ell^{-1}$ of the toxic $\mathrm{Cr}^{+6}$, exceeding the permissible limit of $0.05 \mathrm{mg} \cdot \ell^{-1}$ by a factor of more than 25000 times (NEMA, 1999). Although mean concentrations of copper, nickel, lead and manganese at point sources of metal industries were below the maximum permissible limits, peak values were often up to 10 times higher. As Lake Victoria has an extremely long flushing time, contaminants remain in the water and sediment for long periods. With time, toxic metals are likely to enter the food chain and accumulate in biomass causing cumulative effects in fish-eating organisms including man. The accumulation of metals was higher in shallow near-shore regions and river mouth areas, especially those located close to urban sites (Mwamburi et al., 1997). Long-term effects of toxic compounds on the Lake Victoria ecosystem are poorly understood. Discharge of aluminium sludge from drinking water treatment facilities into wetlands has had a great negative effect on growth of Cyperus papyrus, the dominant macrophyte of economic value in Lake Victoria wetlands (Kaggwa et al., 2001).

The high concentrations of the nutrients $\mathrm{P}$ and $\mathrm{N}$ are important contributors to the increasing eutrophication of Lake Victoria (Hecky and Bugenyi, 1992; Hecky, 1993; Hecky et al., 1994; Mugidde, 2001). Indeed, the continuing proliferation of the water hyacinth, Eichhornia crassipes, in the Ugandan part of Lake Victoria has been linked to the increasing nutrient loads to the lake from the urban and industrial centres (Verschuren et al., 2002; Ogwang and Molo, 2004). Studies on Lake Victoria in the region of Kisumu (Kenya) revealed much higher loads of carbon, phosphorus, nitrogen and metals (Kiragura and Nevejan, 1996) compared to the loads recorded in this study in Uganda. This is probably due to the more industrialised situation around Kenya's Nyasa Gulf, with large tea and sugarcane farms. Water use in industries is substantially higher in Kenya and Tanzania, compared to Uganda (Orindi and Huggins, 2005). However, with the present growth of the Uganda population, a parallel increase in industrial activities is expected to occur. This is likely to rapidly 
increase the pollution and eutrophication originating in the Jinja region to the levels found in Kenya (Scheren et al., 2000).

Wetlands have been shown to be important for wastewater purification, since they absorb soluble and particulate nutrients and form a buffer between the land and the open water. However, due to diffuse water flows and uncontrolled channel formation, the purification efficiency of wetlands is often difficult to evaluate and is also very often low. A model study of the buffering capacity suggests that phosphorus is strongly retained within wetlands, while organic matter and nitrogen (as nitrate) are mostly exported into the lake (Mwanuzi et al., 2003). In many places, wetlands disappear or degrade, mainly through human activities (Balirwa, 2002). As a consequence, large shifts in biodiversity are observed in the wetlands as well as in aquatic communities in the lake. With time, continuing wetland degradation can be expected to cause a progressive decline in the types and quantities of benefits and services that these wetlands provide to the local population, including their roles as sources of food and raw materials, as habitat for wildlife, and for hydrological stability.

\section{Conclusions and recommendations}

This paper has focused on a small number of significant pollution point sources which illustrate the urgent need for on-site effluent pretreatment and continuous monitoring of industrial effluents in Uganda. With the present primitive process technology, fish filleting at Gomba and Agro-Marine and Kengrow Industries will continue to enrich Napoleon Gulf with key nutrients and easily degradable carbon compounds, leading to further oxygen depletion in Lake Victoria. The Leather Industries of Uganda plant discharges high loads of toxic $\mathrm{Cr}^{+6}$; this substance is likely to accumulate in the wetlands and pollute Napoleon Gulf if it is not treated at the plant. Except for Gomba and Leather Industries of Uganda, the companies monitored in this study lacked any on-site pretreatment system. This is a situation that should alert the Uganda National Environment Management Authority to enforce Uganda's National Environment Statute (NEMA, 1995).

With increased urbanisation and socio-economic activities in Jinja's industrial sector, the load of nutrients and pollutants entering Lake Victoria will continue to increase and further diminish the quality of the lake water. Introduction of costeffective cleaner production technologies must be enforced, such as on-site waste separation and reduction, and effluent recycling, coupled with an urgent requirement for increased and compulsory training of the personnel at industrial plants and the proper maintenance of the treatment facilities. The overall environmental management strategy for Jinja has also to insist on a broad multidisciplinary approach including acting on the behaviour of the population because people living in the catchment area act simultaneously as resource users and as polluters (Bugenyi and Balirwa, 1989). The Lake Victoria environmental management project, LVEMP, which was started several years ago, has already concentrated on some of these problems, and its activities will further assist in reaching the goals envisaged (Orach-Meza, 2001; UN-HABITAT, 2004).

\section{Acknowledgements}

The authors thank the Swiss National Science Foundation (Project No. 5001-44774) who funded this fieldwork study. We thank the staff of the Fisheries Resources Research Institute for professional guidance and help. We are indebted to the Jinja
Municipal Council for information on Jinja’s industrial sector, and to the management and workers of the industrial plants for providing information and allowing us to take samples. We furthermore thank Dr. Corinne Wacker for advice to set up the questionnaire, Dr. Markus Wiggli for fruitful discussions and William Okello and Henry Ocaya for technical support.

\section{References}

BALIRWA JS (2001) From vegetation to fish: structural aspects and related components of lakeshore wetlands in Lake Victoria. Paper presented at the LVEMP Conference Kisumu, Kenya.

BOOTSMA HA and HECKY RE (2003) A comparative introduction to the biology and limnology of the African Great Lakes. J. Great Lakes Res. 29 (Suppl.2) 3-18.

BUGENYI FWB and BALIRWA JS (1989) Human intervention in the natural process of the Lake Victoria Ecosystem, the Problem. In: Salanki J and Heredek S (eds.) Conservation and Management of Lakes. 311-340.

BYAMUKAMA D, KANSIIME F, MACH RL and FARNLEITNER AH (2000) Determination of Escherichia coli contamination with Chromocult coliform agar showed a high level of discrimination efficiency for differing fecal pollution levels in tropical waters of Kampala, Uganda. Appl. Environ. Microbiol. 66 (2) 864-868.

CAMPELL LM, HECKY RE and WANDERA SB (2003a) Stable isotope analyses of food web structure and fish diet in Napoleon and Winam Gulfs, Lake Victoria, East Africa. J. Great Lakes Res. 29 (Suppl.2) 243-257.

CAMPELL LM, HECKY RE, MUGGIDE R, DIXON DG and RAMLAL PS (2003b) Variation and distribution of total mercury in water, sediment and soil from northern Lake Victoria, East Africa. Biogeochem. 65 195-211

CHAPMAN D (1992) Water Quality Assessments, A Guide to the Use of Biota, Sediments and Water in Environmental Monitoring. Chapman and Hall, New York. 585 pp.

DENNY P (1988) Assessing of Uganda's Wetlands with Recommendations for Their Management. United Nations Environment Program, Nairobi, Kenya.

DENNY P (2001) Research, capacity-building and empowerment for sustainable management of African wetland ecosystems. Hydrobiol. 458 (1-3) 21-31.

HARRO Z (1996) A Systematic Assessment of Water Pollution in Lake Victoria. M.Sc. Thesis, Eindhoven University of Technology, Eindhoven.

HECKY RE (1993) The eutrophication of Lake Victoria. Verh. Int. Verein. Limnol. 25 39-48.

HECKY RE and BUGENYI FWB (1992) Hydrology and chemistry of African Great Lakes and water quality issues. Problems and solutions. Verh. Int. Verein. Limnol. 23 45-54.

HECKY RE, BUGENYI FWB, OCHUMBA P, TALLING JF, MUDIGGE R, GOPHEN M and KAUFMAN L (1994) Deoxygenation of the deep water of Lake Victoria, East Africa. Limnol. Oceanogr. 39 23-36.

JINJA MUNICIPALITY (1997) State of Environment Report for Jinja Municipality. Kampala Development Consultants Int.-Ldt.

KAGGWA RC, MULALELO CI, DENNY P and OKURUT TO (2001) The impact of alum discharges on a natural tropical wetland in Uganda. Water Res. 35 (3) 795-807.

KANSIIME F and NALUBEGA M (2000) Wastewater Treatment by a Natural Wetland: The Nakivubo Swamp, Uganda - Processes and Implications. Balkema, Rotterdam, NL. 316 pp.

KANSIIME F, KATEYO E and OKOT-OKUMU J (1995) Effects of Pollution of Inner Murchison Bay (Lake Victoria, Uganda) on the Distribution and Abundance of Plankton. NUFU report, Faculty of Science, Makerere University, Kampala, Uganda. 30 pp.

KIRAGURA D and NEVEJAN N (1996) Identification of Pollution Sources in the Kenyan Part of the Lake Victoria Catchment Area. Kenya-Belgium Joint Project in: Freshwater Ecology. Kenya Marine Fisheries Research Institute, Kisumu and Laboratory of General Botany and Nature Management (APNA), Brussels, Belgium. 5 38-50. 
KOLLER M and KUNZ A (1997) Wetland survey. FIRRI-Swiss Ecotone Project, Jinja, Uganda. Report of a GPS Survey in Three Wetlands. ETHZ, Swiss Federal Institute of Technology Zurich and Fisheries Research Institute in Jinja, Uganda

LINDENSCHMIDT KE, SUHR M, MAGUMBA MK, HECKY RE and BUGENYI FWB (1998) Loading of solute and suspended solids from rural catchment areas flowing into Lake Victoria in Uganda. Water Res. 32 (9) 2776-2786.

MUGIDDE R (1993) The increase of phytoplankton productivity and biomass in Lake Victoria (Uganda). Int. Assess. Theor. Appl. Limnol. Proc. 25 846-849.

MUGIDDE R, (2001) Nutrient Status and Planktonic Nitrogen Fixation in Lake Victoria, Africa. Ph.D. Thesis. University of Waterloo, Ontario, Canada.

MWAMBURI J and OLOO FN (1997) The Distribution and concentration levels of trace metals in water and sediments of Lake Victoria, Kenya. Afr. J. Trop. Hydrobiol. Fish. 7 37-48.

MWANUZI F, AALDERINK H and MDAMO L (2003) Simulation of pollution buffering capacity of wetlands fringing the Lake Victoria. Environ. Int. 29 95-103.

NEMA (1995) The National Environment Management Authority, Statute, Supplement No. 3. Uganda, Statutes supplement to the Uganda Gazette Volume LXXXVIII No. 21 dated $19^{\text {th }}$ May 1995. Sections 20-38.

NEMA (1999) The National Environment Regulations, (Standards for Discharge of Effluent into Water or on Land). Statutory Instruments Supplement to the Uganda Gazette Volume XCII No. 7 dated $12^{\text {th }}$ February. 12-14.

NTIBA MJ, KUDOJA WM and KIREMA-MUKASA CT (2000) Problems related to water: the situation in Lake Victoria basin, East Africa. Boll. Soc. Ticinese Sci. Nat. 88 109-116.

ODADA EO, OLAGO DO, KULINDWA K, NTIBA M and WANDIGA S (2004) Mitigation of environmental problems in Lake Victoria, East Africa: Causal chain and policy options analyses. Ambio 33 (1-2) 13-23.
OGWANG JA and MOLO R (2004) Threat of water hyacinth resurgence after a successful biocontrol program: Biocontrol. Sci. Technol. 6 623-626.

ORACH-MEZA FL (2001) Lake Victoria Environmental Management Project, Initiative in the management of trans-boundary waters. Proc. Int. Conf. Freshwater. Bonn, Germany. Available at www. lvemp.org/L_Publications/Uganda/Dr\%20Orach\%20-\%20Bonn. htm.

SAAD MAH (1987) Limnological studies on the Nozha Hydrodrome, Egypt, with special reference to the problems of pollution. Sci. Total Environ. 67 195-214.

SAAD MAH, AMUZU AT, BINEY C, CALAMARI D, IMEVBORE AM, NAEVE H and OCHUMBA PBO (1990) Scientific Bases for Pollution Control in African Inland Waters (Domestic and industrial organic loads). FAO Fisheries Report 437. 24 pp.

SCHEREN PAGM, ZANTING HA and LEMMENS AMC (2000) Estimation of water pollution sources in Lake Victoria, East Africa: Application and elaboration of the rapid assessment methodology. J. Environ. Manage. 58 235-248.

STANDARD METHODS (1998) Standard Methods for the Examination of Water and Wastewater. Clesceri LS, Greenberg AE, Eaton AD (eds.) (20 ${ }^{\text {th }}$ edn.) American Public Health Association (APHA) Washington DC.

UN-HABITAT (2004) Project proposal: Lake Victoria region water and sanitation initiative, available at http://temp.itpreneurs.com/lake $\% 2$ 0victoria\%20initiative.pdf

VERSCHUREN D, JOHNSON TC, KLING HJ, EDINGTON DN, LEAVITT R, BROWN ET, TALBOT MR and HECKY RE (2002) History and timing of human impact on Lake Victoria, East Africa. Proc. R. Soc. Lond. B 269 289-294.

WILLIAMS GM (1991) Techniques and Fieldwork in Ecology. Bell and Hyman, London.

WHO (1984) World Health Organisation. Drinking Water Guidelines. Available at www.who.int/water sanitation health/dwg/gdwq3/en/ index.html 